Postgraduate Bosowa University Publishing (PBUP)
Indonesian Journal of Business and Management
e-ISSN: $2460-3767 \quad p$-ISSN: $2656-6885$
INttps://postgraduate.universitas
JOURAL

\title{
FAKTOR-FAKTOR YANG MEMPENGARUHI PENERIMAAN PENDAPATAN ASLI DAERAH PADA DINAS PENDAPATAN KEUANGAN DAN ASET DAERAH KABUPATEN MAJENE
}

\author{
Analysis of Factors Affecting Local Own-source Revenue in Regional Revenue, Finance, and Asset Office \\ of Majene Regency
}

\author{
Mahfudh $^{1}$, Haeruddin Saleh ${ }^{2}$, Muhammad Yusuf Saleh ${ }^{3}$ \\ ${ }^{1}$ Mahasiswa Magister Manajemen Universitas Universitas Bosowa \\ ${ }^{2}$ Program Stud Manajemen Program Pascasarjana Universitas Bosowa \\ Email: mahfudhmustakim@gmail.com
}

Diterima: 22 Januar 2021/Disetujui: 02 Jun 2021

\begin{abstract}
ABSTRAK
Penelitian ini bertujuan untuk mengetahui: (a) pengaruh pendapatan perkapita terhadap pendapatan asli daerah. (b) pengaruh jumlah perusahaan terhadap pendapatan asli daerah. (c) pengaruh jumlah penduduk terhadap pendapatan asli daerah. (d) faktor dominan yang berpengaruh terhadap pendapatan asli daerah. Penelitian ini bersifat kausal dengan tipe konklusif berstruktur dan sistematik untuk menentukan hubungan sebab-akibat beberapa variabel. Teknik pengumpulan data menggunakan studi kepustakaan dan data sekunder pendapatan asli daerah Kabupaten Majene tahun 2014-2018. Hasil penelitian menunjukkan (a) pendapatan perkapita berpengaruh secara positif dan signifikan terhadap pendapatan asli daerah Kabupaten Majene Tahun 2014-2018. Pertumbuhan pendapatan perkapita dengan trend positif dapat meningkatkan jumlah pendapatan asli daerah. (b) Jumlah perusahaan berpengaruh positif dan signifikan terhadap pendapatan asli daerah Kabupaten Majene Tahun 2014-2018. Semakin banyak jumlah perusahaan maka akan menambah kontribusi pajak ke Pemerintah Daerah Kabupaten Majene. (c) Jumlah penduduk berpengaruh secara positif dan signifikan terhadap pendapatan asli daerah Kabupaten Majene Tahun 2014-2018. Peningkatan jumlah penduduk akan meningkatkan pendapatan yang ditarik dari subyek pajak (penduduk) secara berkesinambungan. (d) Pendapatan perkapita merupakan faktor yang paling dominan dalam berkontribusi meningkatkan pendapatan asli daerah Kabupaten Majene Tahun 2014-2018.
\end{abstract}

Kata Kunci: Nilai Pendapatan Asli Daerah; Pendapatan per kapita; Jumlah Perusahaan dan Populasi

\section{ABSTRACT}

This research aims to determine (a) the influence of percapita income on local own-source revenue. (b) the effect of the number of companies on local own-source revenue. (c) the effect of population on local own-source revenue. (d) the dominant factor that affects local own-source revenue. This research is causal, structured and systematic type of study which determines the cause-effect relationship of several variables. The data collection technique uses literature study and secondary data of local own-source revenue from Majene Regency between 2014 and 2018. The results showed that (a) Per capita income had a positive and significant effect on the local own-source revenue of Majene Regency in 2014-2018. The growth of per capita income with a positive trend can increase the amount of local own-source revenue. (b) The number of companies had a positive and significant effect on the local own-source revenue of Majene Regency in 2014-2018. The more companies that were established, the more tax contribution will be added to the Regional Government of Majene Regency. (c) The population had a positive and significant effect on the local own-source revenue of Majene Regency in 2014-2018. Increasing the number of residents would increase the income drawn from the tax subject (resident) continuously. (d) Per capita income was the most dominant factor contributing to increasing of the local own-source revenue of Majene Regency in 2014-2018.

Keywords: Local Own-source Revenue, Percapita Income, Number of Compaies and Population 


\section{PENDAHULUAN}

Pendapatan Asli Daerah (PAD) pendapatan daerah yang berasal dari kegiatan ekonomi daerah itu sendiri merupakan sumber. PAD merupakan salah satu pilar suatu daerah kemandirian. Menurut Undang-Undang Nomor 33 Tahun 2004 tentang Perimbangan Keuangan antara Pemerintah Pusat dan Daerah, sumber menyebutkan bahwa-sumber penerimaan daerah dalam rangka rangka menyelenggarakan Dana perimbangan, otonomi daerah adalah dari PAD, pinjaman daerah dan lain-lain pendapatan daerah yang sah. (1) hasil pajak daerah, (2) hasil dari retribusi daerah, (3) hasil dari perusahaan milik daerah dan hasil pengelolaan kekayaan daerah yang dipisahkan, (4) lain-lain pendapatan daerah yang sah. PAD Terdiri dari; Bersumber Penerimaan PAD dalam wilayahnya sendiri yang dipungut berdasarkan perundang-undangan

Otonomi daerah dan desentralisasi fisikal ini mengharapkan pemerintah daerah memiliki kemandirian yang lebih besar dalam keuangan daerah, oleh karena itu, peranan PAD yang merupakan bagian dari Pendapatan Daerah sangat menentukan kinerja keuangan daerah. Pengukuran kinerja keuangan daerah yang banyak dilakukan saat ini antara lain dengan melihat rasio antara PAD dengan total pendapatan daerah pada APBD. Prinsipnya, semakin besar sumbangan PAD kepada APBD akan menunjukkan semakin kecil ketergantungan daerah kepada pusat. Nyatanya, dalam penyelenggaraan otonomi daerah banyak daerah kabupaten/kota yang tidak mampu membiayai kebutuhan daerahnya. Hal ini dapat dilihat dari kondisi keuangan daerah yang ada selama ini dimana porsi antara PAD dengan sumbangan pemerintah pusat sangat besar sehingga dapat dipastikan bahwa sebagian besar kabupaten/kota di Indonesia memiliki PAD yang sangat kecil dalam membelanjai kebutuhan daerahnya.

Menurut Prana (2016), Hukum mengenai pemerintah daerah tersebut membawa angin segar dalam pelaksanaan desentralisasi, berlakunya. Pemerintah daerah harus dapat mengatur dan mengurus rumah tangganya sendiri, Konsekuensinya. Salah satu pelaksanaannya bergantung pada kemampuan ekonomi meliputi: pertama, tentang bagaimana pemerintah daerah dapat menghasilkan finansial untuk menjalankan organisasi termasuk Daerah melihat fungsinya mengembangkan kemampuan ekonomi daerah bagaimana pemerintah. Dari uraian tersebut maka dapat disimpulkan bahwa ciri utama kemampuan suatu daerah adalah terletak pada kemampuan daerahnya keuangan daerahnya daerah otonom harus memiliki kewenangan dan kemampuan sumber-sumber untuk menggali keuangannya sendiri.

Pelaksanaan otonomi daerah juga diamanatkan dalam Undang-Undang Nomor 22 Tahun 1999, yaitu tentang Pemerintah Daerah. Daerah diberi kewenangan dan tanggung jawab yang lebih besar untuk mengatur dan mengurus kepentingan masyarakat setempat menurut prakarsa sendiri berdasarkan aspirasi masyarakat. Tujuan dari otonomi daerah adalah meningkatkan daya guna dan hasil guna penyelenggaraan pemerintah daerah, terutama dalam pelaksanaan pembangunan dan pelayanan terhadap masyarakat serta meningkatkan pembinaan kestabilan politik dan kesatuan bangsa. Undang-Undang tersebut direvisi dan disempurnakan dengan Undang-Undang Republik Indonesia Nomor 32 Tahun 2004, tentang Pemerintah Daerah direvisi yang kedua menjadi UndangUndang Nomor 12 Tahun 2008, bahwa dalam penyelenggaraan pemerintah daerah sesuai dengan amanat Undang-Undang Dasar Negara Republik Indonesia Tahun 1945, pemerintah daerah yang mengatur dan mengurus sendiri urusan pemerintah menurut asas otonomi dan tugas pembantuan, diarahkan untuk mempercepat terwujudnya kesejahteraan masyarakat melalui peningkatan, pelayanan pemberdayaan dan peran serta masyarakat, serta peningkatan daya saing daerah dengan memperhatikan prinsip demokrasi, pemerataan, keadilan, keistimewaan dan kekhususan suatu daerah dalam dalam sistem Negara Kesatuan Republik Indonesia.

Citra keuangan pemerintah daerah akan tercermin dari besarnya PAD yang diperoleh dan bagaimana alokasi keuangan pemerintah daerah untuk membiayai kegiatan pemerintah daerah untuk mensejahterahkan masyarakatnya. Untuk meningkatkan penerimaan PAD, pemerintah daerah perlu melakukan analisis potensipotensi yang ada di daerah dan mengembangkan potensi tersebut sebagai pemasukan daerah. Pengembangan potensi akan menciptakan pendapatan asli daerah bagi yang berguna untuk melaksanakan tujuan pembangunan. Sehingga dalam proses menuju kemandirian Pengelolaan dan penyelenggeraan pemerintah dalam bidang pembangunan akan mampu tercipta secara berkelanjutan, sebuah daerah dalam bidang pembiyaan. Akan tetapi kenyataanya ini tercermin dari peranan sumbangan atau kontribusi PAD terhadap Anggaran Pemerintah dan Belanja Daerah (APBD) kabupaten/kota yang dirasa masih rendah, khususnya untuk PAD.

Kabupaten Majene, terkait peningkatan pembiayaan daerah yang bersumber dari pendapatan asli daerah, Permasalahan yang sama juga dihadapi oleh pemerintah. Majene dengan fokus penelitian tentang pengaruh pendapatan perkapita, jumlah perusahaan dan jumlah penduduk terhadap penerimaan PAD dengan menggunakan data secon dari periode 2014-2018. Sehingga peneliti berinisiatif melakukan riset di Kabupaten. Sebagai data awal dari penelitian ini, berikut disajikan gambaran makro ekonomi terkait kebijakan keuangan.

Kabupaten Majene Tahun Anggaran 2018 dari Berdasarkan laporan hasil keuangan pemerintah. Majene telah berupaya meningkatkan penerimaan pendapatan asli daerah dengan berbagai cara seperti memperluas cakupan pungutan pajak dan retribusi, efisiensi biaya pungutan dan penyempurnaan mekanisme daerah pengelolaan keuangan. Pemerintah Kabupaten. Perkembangan 
realisasi pendapatan asli daerah Kabupaten Majene selama 5 (lima) tahun terakhir dapat dilihat dari Tabel 1.1 berikut ini:

Tabel 1 Sumber Penerimaan PAD Kabupaten Majene 2014-2018

\begin{tabular}{|c|c|c|c|c|c|c|c|c|c|}
\hline \multirow[b]{2}{*}{ Tahun } & \multirow[b]{2}{*}{$\begin{array}{l}\text { Realisasi } \\
\text { PAD }\end{array}$} & \multicolumn{8}{|c|}{$\begin{array}{l}\text { Sumber-sumber Pendapatan Asli Daerah } \\
\end{array}$} \\
\hline & & $\begin{array}{l}\text { Pajak } \\
\text { Daerah }\end{array}$ & $\%$ & $\begin{array}{l}\text { Retribusi } \\
\text { Daerah }\end{array}$ & $\%$ & $\begin{array}{l}\text { Laba } \\
\text { BUMD } \\
\& \text { Aset } \\
\text { Daerah }\end{array}$ & $\%$ & $\begin{array}{l}\text { Lain- } \\
\text { lain } \\
\text { PAD } \\
\text { yang } \\
\text { Sah } \\
\end{array}$ & $\%$ \\
\hline 2014 & 53.921 & 4.444 & 89,70 & 43.910 & 89,03 & 2.255 & 100 & 3.310 & 113,68 \\
\hline 2015 & 45.231 & 5.634 & 92,48 & 12.086 & 91,90 & 2.655 & 100 & 120.625 & 98,89 \\
\hline 2016 & 50.544 & 6.065 & 80,20 & 12.192 & 89,41 & 3.127 & 100 & 57.698 & 87,30 \\
\hline 2017 & 83.238 & 6.763 & 93,88 & 13.489 & 87,78 & 3.345 & 100 & 59.639 & 93,56 \\
\hline 2018 & 61.831 & 7.666 & 69,94 & 13.796 & 86,02 & 2.686 & 100 & 93.176 & 78,81 \\
\hline
\end{tabular}

Dalam Tabel 1.1 menjelaskan bahwa asli pendapatan tahun 2014-2018 dari pajak daerah sebesar 89,70\% 69,94 , retribusi daerah sebesar 89,03\% - 86,02\%, pendapatan hasil pengelolaan kekayaan daerah yang dipisahkan sebesar $100 \%$, lain-lain PAD yang sah sebesar $113,68 \%$ - 78,81\%. Selama periode 5 (lima) tahun, anggaran Kabupaten Majene realisasi penerimaan pendapatan asli daerah bervariasi. Dengan nilai pendapatan pajak daerah terendah pada tahun 2018 sebsar 69,94\% dan puncak tertinggi pada tahun 2017 sebesar $93.88 \%$. Penurunan pendapatan asli daerah ini disebabkan lemahnya peningkatan pajak dan retribusi daerah. Dapat juga dilihat dari sumber pendapatan lain yang mengalami penurunan pada tahun 2018. Ini dikarenakan semakin rendahnya pendapatan perkapita masyarakat, kurangnya kesadaran masyarakat untuk membayar pajak dan semakin kecilnya jumlah perusahaan sehingga memberikan kontribusi kecil kepada pajak dan retribusi daerah.

Untuk melihat potensi sumber penerimaan suatu daerah sendiri (Provinsi/Kabupaten) dibutuhkan pengetahuan tentang perkembangan beberapa faktorfaktor "Yang dapat dikendalikan" (yaitu faktor-faktor kebijakan dan kelembagaan), dan "yang tidak dapat dikendalikan", (yaitu variabel-variabel ekonomi) yang dapat mempengaruhi kekuatan sumber-sumber penerimaan daerah, Beberapa faktor-faktor tersebut adalah : (1) Kondisi awal suatu daerah, (2) Peningkatan cakupan atau ekstensifikasi dan intensifikasi penerimaan, (3) Perkembangan Pendapatan Domestik Regional Bruto (PDRB) perkapita riil, (4) Pertumbuhan penduduk, (5) Tingkat inflasi, (6) Penyesuaian tarif, (7) Pembangunan baru, (8) Sumber pendapatan baru, (9) Perubahan peraturan.

Pendapatan Asli Daerah merupakan sumber pendapatan murni daerah yang terdiri dari hasil pajak daerah, hasil retribusi daerah, hasil pengelolaan kekayaan daerah yang dipisahkan, dan lain-lain pendapatan asli yang sah. Semua pendapatan daerah itu mempunyai peranan penting dalam keuangan daerah yang merupakan salah satu tolak ukur di dalam pelaksanaan otonomi daerah yang luas, nyata, dan bertanggung jawab secara proporsional. Pada hakikatnya retribusi daerah lebih beraneka ragam dan bervariasi antara daerah yang satu dengan yang lain. Semakin maju suatu daerah akan semakin banyak fasilitas atau jasa yang perlu disediakan untuk pemenuhan kegiatan ekonomi dan sosial masyarakat sehingga semakin banyak pula jasa-jasa retribusi yang dapat dipungut oleh daerah.

Untuk menilai sejauh mana pembangunan bidang ekonomi yang telah dilaksanakan maka sangat diperlukan adanya alat untuk mengukur tingkat keberhasilan pembangunan tersebut. Pendapatan regional adalah suatu indikator berupa data agregat yang sampai saat ini banyak negara termasuk Indonesia masih memakai data tersebut untuk mengukur tingkat pertumbuhan ekonomi, baik secara nasional maupun regional. PDRB merupakan data statistik untuk memberikan gambaran-gambaran keadaan ekonomi baik di masa lalu maupun sekarang dan sebagai evaluasi, perencanaan, dan sasaran yang akan dicapai masa mendatang.

Produk Domestik Regional Bruto adalah merupakan nilai tambah bruto seluruh barang jasa yang tercipta atau dihasilkan secara domestic suatu Negara yang timbul akibat berbagai aktivitas ekonomi dalam suatu priode tertentu tanpa memperhatikan apakah faktor produksi yang dimiliki residen atau non-residen (PDRB Kabupaten Majene, 2019).

Data PDRB ini diperlukan untuk mengetahui : (a) PDRB Harga berlaku (nominal) menunjukkan kemampuan sumber daya ekonomi yang dilakukan oleh suatu wilayah. Nilai PDRB yang Besar menunjukkan kemampuan sumber daya ekonomi yang besar, begitu juga sebalikya; (b) PDRB Harga konstan (rill) dapat digunakan untuk menunjukkan laju ekonomi secara keseluruhan atau setiap ekonomi dari tahun ke tahun; (c) Distribusi PDRB harga berlaku menurut lapangan usaha menunjukkan struktur prekonomian atau peranan setiap ekonomi dalam suatu wilayah. Kategori-kategori ekonomi yang mempunyai peranan besar menunjukkan basis ekonomi suatu wilayah; (d) PDRB per kapita atas dasar harga berlaku menunjukkan Produk Domestik Bruto (PDB) dan Produk Nasional Bruto (PNB) per satu orang penduduk; (e) PDRB per kapita atas harga konstan berguna untuk mengetahui pengetahuan nyata untuk ekonomi perkapita untuk penduduk suatu Negara. PDRB atas dasar harga dikenal dengan PDRB nominal disusun berdasarkan harga yang berlaku pada periode perhitungan dan bertujuan untuk melihat struktur perekonomian. Sedangkan PDRB atas dasar harga konstan disusun berdasarkan harga pada tahun dasar dan bertujuan untuk mengukur pertumbuhan ekonomi (PDRB Kabupaten Majene, 2019).

Penerimaan daerah perlu terus diupayakan dengan peningkatan adanya penggalian potensi sumber-sumber dana yang ada sehingga dapat menyelenggarakan pemerintahan, pembangunan, dan pelayanan masyarakat yang semakin meningkat kuantitas dan kualitasnya. Upaya perbaikan sangat diperlukan terutama di bidang pengelolaan keuangan daerah. Berbagai kebijakan tentang keuangan daerah diarahkan agar kemampuan daerah meningkat dalam membiayai penyelenggaraan urusannya sesuai dengan prinsip-prinsip otonomi daerah dengan diberikannya kewenangan oleh pemerintah pusat berupa kewenangan yang kuat, nyata, dan bertanggung jawab 
secara. Untuk mempercepat tercapainya kemandirian suatu daerah, diperlukan kontribusi khususnya pada perusahaan-perusahaan swasta dalam sumber lain-lain PAD yang sah. Namun, pemerintah daerah harus ikut dalam membuka pangsa pasar domestik dan internasional. Dengan kualitas dan kuantitas produk yang tinggi sehingga pangsa pasar yang dihasilkan dari produk akan lebih luas sehingga perusahaan-perusahaan tersebut dapat memberikan kontribusi yang tinggi terhadap PAD.

Pertambahan penduduk merupakan suatu hal yang dibutuhkan dan bukan suatu masalah, melainkan sebagai unsur penting yang dapat memacu pembangunan ekonomi (Nyoman dan Murjayanasa, 2017). Peningkatan jumlah penduduk akan berdampak pada peningkatan pendapatan, dalam hal ini PAD juga akan meningkat. Jumlah penduduk merupakan salah satu faktor penentu adanya disparitas pendapatan daerah. Hasil penelitian yang dilakukan oleh Asmurf, dkk (2015) menunjukkan bahwa jumlah penduduk berpengaruh positif dan signifikan terhadap PAD. Hal ini berarti semakin banyaknya jumlah penduduk maka PAD akan meningkat.

Berdasarkan teori klasik menjelaskan kaitan antara pendapatan perkapita dengan jumlah penduduk. Teori tersebut dinamakan teori penduduk optimal. Dari teori pertumbuhan klasik dapat dilihat bahwa apabila terdapat kekurangan penduduk, produksi marjinal adalah lebih tinggi dari pada. Maka pertambahan penduduk akan menaikkan pendapatan perkapita, akan tetapi apabila penduduk sudah semakin banyak, hukum hasil lebih yang semakin berkurang akan mempengaruhi fungsi produksi, pendapatan perkapita. Pendapatan perkapita menjadi semakin lambat pertumbuhannya Oleh karenanya, Penduduk yang bertambah terus suatu jumlah penduduk tertentu produksi marginalnya sama dengan pendapatan perkapita akan menyebabkan suatu. Pada keadaan ini pendapatan maksimal perkapita mencapai nilai (Sadono Sukirno, 1999).

Berdasarkan uraian tersebut mendorong penulis untuk meneliti dan lebih mencermati "Analisis FaktorFaktor yang Mempengaruhi Penerimaan Pendapatan Asli Daerah pada Dinas Pendapatan Keuangan dan Aset Daerah Kabupaten Majene".

\section{METODE}

Jenis penelitian yang digunakan adalah kausal dengan tipe konklusif berstruktur dan sistematik yang bertujuan untuk menentukan hubungan sebab-akibat (hubungan kausal) dari suatu fenomena mengenai situasi yang ada dengan cara mengamati antara variabel bebas dan variabel terikat dilakukan secara serentak pada individual dari suatu populasi pada satu saat (Murti,B 2003). Faktual dan akurat mengenai fakta-fakta dan sifatsifat populasi atau daerah tertentu, Dilakukan secara sistematis. Data sekunder dan pada waktu berurutan (times serries) tahun 2014-2018 selanjutnya dilakukan pengujian atas data dari Penggalian data berdasarkan. Metode data analisis menggunakan analisis regresi linier berganda, dengan membuat hipotesa dan asumsi klasik untuk memperoleh fungsi linier berganda, dengan membuat hipotesa dan asumsi.

\section{HASIL DAN PEMBAHASAN}

Data yang digunakan dalam penelitian ini merupakan data yang diperoleh pada Badan Pendapatan Asli Daerah Kabupaten Majene tahun 2014-2018. Diantaranya, penerimaan PAD, pendapatan perkapita, jumlah perusahaan dan jumlah penduduk.

1. Variabel Penerimaan PAD

Variabel PAD pada penelitian ini diartikan sebagai penerimaan PAD Badan Pendapatan Asli Daerah Kabupaten Majene tahun 2014-2018. Pengukuran variabel penerima PAD dinyatakan dalam jumlah rupiah pertahun.

Tabel 2 Pertumbuhan PAD Tahun 2014-2018

\begin{tabular}{ccc}
\hline Tahun & PAD & Pertumbuhan $(\%)$ \\
\hline 2014 & $53.921 .491 .920,68$ & - \\
2015 & $45.231 .988 .393,56$ & $-16,12$ \\
2016 & $50.544 .269 .254,29$ & 11,75 \\
2017 & $83.238 .103 .847,80$ & 64,70 \\
2018 & $61.813 .947 .197,07$ & $-25,74$ \\
\hline Rata-Rata & $7.892 .455 .276,39$ & 8,65 \\
\hline
\end{tabular}

Sumber: BAPENDA Kab. Majene 2020

Tabel 2 menunjukkan hasil penelitian diporelah data mengenai pertumbuhan PAD yang diterima Kantor BPAD tahun 2014-2018, anggaran pendapatan Pemerintah ditahun 2015 menurun dan meningkat kembali di tahun 2016 sampai dengan tahun 2017 dan kembali menurun di tahun 2018. Hal ini juga menunjukkan rata-rata realisasi PAD sebesar Rp. 7.892.455.276,39 dengan pertumbuhan rata-rata $8,65 \%$. Pertumbuhan tertinggi $64,70 \%$ pada tahun 2017, sedangkang pertumbuhan terendah $-25,74 \%$ pada tahun 2018. Hal ini belum dapat menjelaskan apakah pertumbuhan PAD menunjukkan hasil yang baik atau malah sebaliknya pada pemerintah Kabupaten Majene.

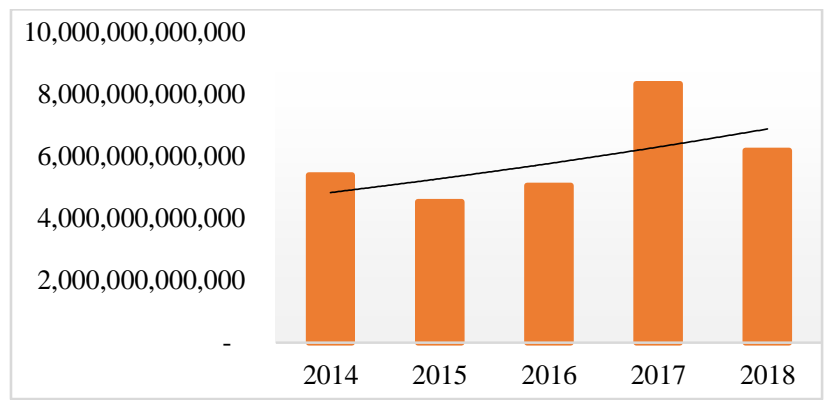

Sumber : Data Sekunder Diolah, BPAD Kab, Majene 2020

Gambar 1 Diagram Garis Pertumbuhan PAD.

Gambar diatas menunjukkan pertumbuhan PAD selama tahun 2014-2018 sangat bervariasi, mengalami pertumbuhan sangat kecil pada tahun 2018 dan pertumbuhan tertinggi pada tahun 2017. 
2. Variabel Pendapatan Perkapita

Salah satu ukuran yang digunakan untuk mengukur tingkat kemakmuran penduduk suatu daerah/wilayah adalah PDRB per kapita. Besarnya pendapatan per kapita merupakan salah satu indikator untuk mengukur tingkat kesejahteraan penduduk. Nilai PDRB per kapita diperoleh dari hasil bagi antara PDRB dengan jumlah penduduk pertengahan tahun, dengan demikian besarnya penduduk suatu daerah sangat mempengaruhi tinggi rendahnya pendapatan per kapita daerah tersebut. Dengan perhitungan bahwa PDRB berdasarkan harga konstan pertengahan tahun dibagi jumlah penduduk. Kabupaten Majene tahun 2014-2018 Data sekunder diperoleh dari Badan Pusat Statistik (BPS).

Table 3 Pertumbuhan Pengeluaran Perkapita

\begin{tabular}{ccc}
\hline Tahun & Pengeluaran Perkapita & $\begin{array}{c}\text { Pertumbuhan } \\
(\%)\end{array}$ \\
\hline 2014 & $12.368,048$ & - \\
2015 & $13.648,150$ & $8,12 \%$ \\
2016 & $14.757,581$ & $5,65 \%$ \\
2017 & $15.592,691$ & $6,48 \%$ \\
2018 & $16.603,173$ & $6,10 \%$ \\
\hline Rata-Rata & $4.235,125$ & $6,58 \%$ \\
\hline
\end{tabular}

Sumber : BPS Kabupaten Majene

Table 3 menunjukkan hasil penelitian diperoleh data dengan pertumbuhan sangat bervariasi. Dengan nilai pertumbuhan terendah sebesar 5,65\% pada tahun 2016 dan tertinggi sebesar 8,12\% pada tahun 2015 .

GRAFIK

PENGELUARAN PERKAPITA

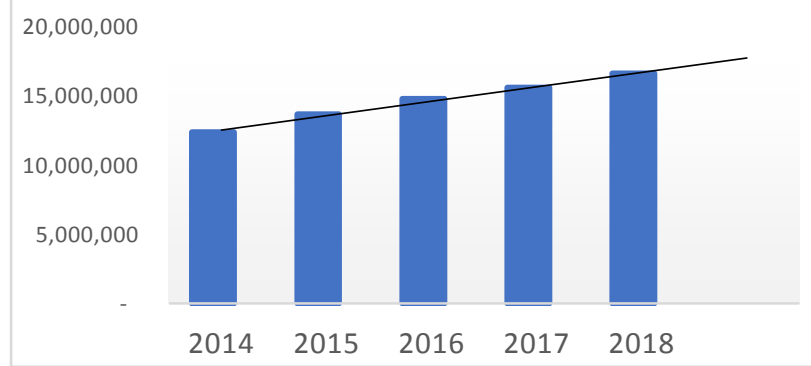

Sumber : Data sekunder diolah, BPS Kab. Majene 2020

Gambar 2 Diagram Garis Pertumbuhan Pengeluaran Perkapita.

2014-2018 sangat bervariasi, mengalami pertumbuhan rendah pada tahun 2014. Gambar diatas menunjukkan pertumbuhan pengeluaran perkapita selama tahun. 2018 juga merupakan pertumbuhan tertinggi pada jumlah perusahaan karena banyak pembangunan perusahaan/pabrik baru, Pertumbuhan tertinggi pada tahun.

3. Variabel jumlah perusahaan

Variabel Jumlah Perusahaan dalam sebagai jumlah perusahaan selama tahun peneilitian ini diartikan 20142018. BPS Kabupaten Majene pada tahun 2020 data sekunder diperoleh dari. Jumlah Pengukuran Perusahaan Dinyatakan Dalam Perusahaan Pertahun.
Table 4 Pertumbuhan Jumlah Perusahaan

\begin{tabular}{ccc}
\hline Tahun & Jumlah Perusahaan & $\begin{array}{c}\text { Pertumbuhan } \\
(\%)\end{array}$ \\
\hline 2014 & 117 & - \\
\hline 2015 & 119 & 1,70 \\
\hline 2016 & 393 & 230,25 \\
\hline 2017 & 465 & 18,32 \\
\hline 2018 & 453 & $-2,58$ \\
\hline Rata-Rata & 84 & 61,92 \\
\hline
\end{tabular}

Sumber : BPS Kabupaten Majene, 2020

Pada Tabel 4 menunjukkan, berdasarkan hasil penelitian diperoleh data mengenai jumlah perusahaan yang bersumber dari BPS Kabupaten Majene selama tahun 2014-2018 didapatkan pertumbuhan jumlah pertumbuhan sangat bervariasi. Dengan nilai pertumbuhan terendah (negatif) $-2,58 \%$ pada tahun 2018 dan tertinggi $230,25 \%$, pada tahun 2016 .

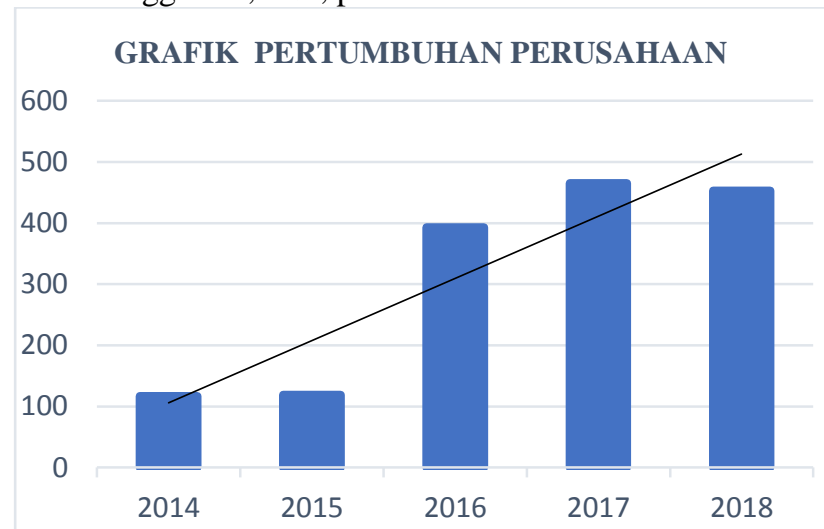

Sumber : Data skunder diolah, BPS Kab, Majene 2020

Gambar 3 Diagram Garis Pertumbuhan Perusahaan

Gambar diatas menunjukkan bahwa pertumbuhan perusahaan dari tahun 2014-2018 sangat bervariasi, kembali mengalami pertumbuhan paling kecil (negatif) pada tahun 2018 dan mengalami pertumbuhan tinggi yang mencapai puncak pada tahun 2016 selama 5 (lima) tahun terakhir.

4. Variabel jumlah penduduk

Maupun warga negara asing bertempat tinggal tetap di dalam wilayah peraturan perundang-undangan yang berlaku. Variabel Jumlah Penduduk dalam penelitian ini diartikan sebagai totalitas sejumlah warga negara Indonesia Pengukran jumlah penduduk dinyatakan dalam jumlah jiwa pertahun penduduk jumlah jiwa pertahun.

Tabel 5 Pertumbuhan Jumlah Penduduk

\begin{tabular}{ccc}
\hline Tahun & Jumlah Penduduk & $\begin{array}{c}\text { Pertumbuhan } \\
(\%)\end{array}$ \\
\hline 2014 & 161.132 & - \\
2015 & 163.896 & 0,76 \\
2016 & 166.397 & 1,52 \\
2017 & 169.072 & 1,60 \\
2018 & 171.272 & 1,30 \\
\hline Rata-Rata & 10.140 & 1,29 \\
\hline
\end{tabular}

Sumber : BPS Kabupaten Majene, 2020

Tabel 5 menunjukkan hasil penelitian diperoleh data mengenai pertumbuhan penduduk pada kantor Badan 
Pusat Statistik (BPS) tahun 2014-2018, dengan nilai pertumbuhan terendah $0,76 \%$ pada tahun 2015. Pertumbuhan tertinggi $1,60 \%$ pada tahun 2017.

\section{GRAFIK PERTUMBUHAN PENDUDUK}

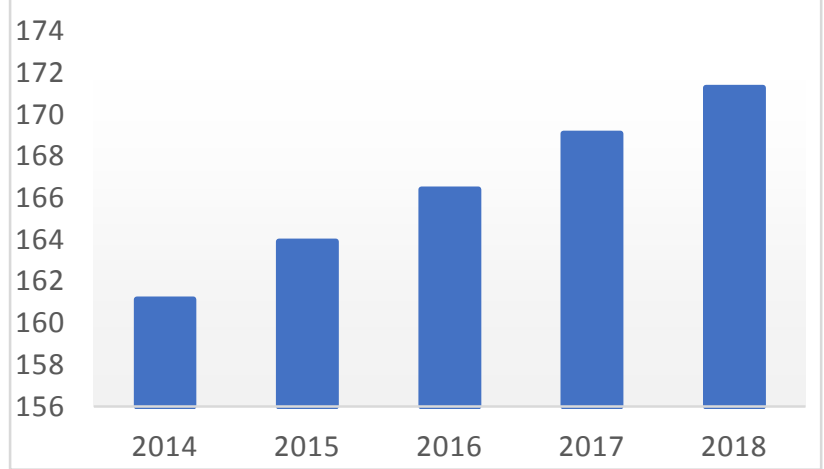

Sumber : Data skunder diolah, BPS Kab. Majene 2020

Gambar 4 Diagram Garis Pertumbuhan Penduduk

Gambar diagram garis diatas menunjukkan pertumbuhan penduduk selama tahun 2014-2018 bervariasi, mengalami pertumbahan tertinggi pada tahun 2017 dan pertumbuhan terendah di tahun 2015.

1. Pengaruh Pendapatan Perkapita Terhadap Pendapatan Asli Daerah Kabupaten Majene Tahun 2014-2018

Total nilai barang dan jasa akhir yang dihasilkan oleh berbagai unit produksi di dalam suatu daerah dalam jangka waktu tertentu pendapatan perkapita sebagai jumlah. PDRB berdasarkan harga konstan dibagi dengan perhitungan bahwa dengan jumlah penduduk pertengahan tahun.

Hasil penelitian ini membuktikan bahwa pendapatan perkapita berpengaruh secara positif dan signifikan terhadap pendapatan asli daerah Kabupaten Majene Tahun 2014-2018. Setiap terjadi kenaikan 1 skor pendapatan perkapita, maka akan diikuti oleh kenaikan pendapatan asli daerah sebesar 3,530 satuan. Pertumbuhan positif pendapatan perkapita dapat meningkatkan jumlah pendapatan asli daerah Kabupaten Majene.

Berdasarkan undang-undang nomor 33 tahun 2004 tentang Perimbangan Keuangan Antara Pemerintah Pusat Dan Pemerintahan Daerah Pendapatan Asli Daerah, yang disebut pendapatan asli daerah adalah pendapatan yang diperoleh daerah yang dipungut berdasarkan Peraturan Daerah sesuai dengan peraturan perundang-undangan. Salah satu sumber pendapatan asli daerah berdasarkan undang-undang nomor 33 tahun 2004 adalah Pendapatan Asli Daerah.

Pendapatan perkapita mampu berkontribusi meningkatkan pendapatan asli daerah Kabupaten Majene, hal ini sesuai pernyataan para ahli ekonomi seperti Adolf Wagner dalam Amiruddin (2016) mengemukakan bahwa dalam suatu perekonomian, apabila pendapatan perkapita meningkat secara relatif pengeluaran pemerintah pun akan ikut meningkat, Wagner menjelaskan peranan pemerintah yang semakin besar karena pemerintah harus mengatur hubungan yang timbul dalam masyarakat, hukum pendidikan, kebudayaan dan sebagainya.

Pada tahun 2014-2018 pertumbuhan pendapatan (pengeluaran) perkapita tertinggi pada tahun 2018 dan terendah pada tahun 2014 dengan nilai rata-rata 5 tahun terakhir mencapai Rp. 4.234.125,- . Secara year on year pendapatan perkapita tumbuh dalam 5 tahun terakhir sehingga mampu berkontribusi meningkatkan pendapatan asli daerah Kabupaten Majene Tahun 2014-2018. Semakin besar nilai pendapatan perkapita pada suatu daerah, diasumsikan bahwa tingkat kesejahteraan masyarakat meningkat.

Hasil Survei Sosial Ekonomi Nasional Badan Pusat Statistik Tahun 2014-2015 bahwa Rata-rata Pengeluaran Per Kapita Sebulan Menurut Jenis Pengeluaran dan Daerah 2014-2015, pada tahun 2014 pengeluaran perkapita di kota maupun di desa mencapai 479.773 kemudian di tahun 2015 meningkat menjadi 563.345. Pertumbuhan positif ini mengindikasikan bahwa pendapatan perkapita masyarakat majene mengalami peningkatan signifikan demikian juga kesejahteraanya.

Hasil penelitian ini sesuai dengan pernyataan ahli bahwa salah satu tujuan utama dari desentralisasi fiskal adalah terciptanya kemandirian daerah. Pemerintah daerah diharapkan mampu mengali sumber-sumber keuangan lokal, khususnya melalui Pendapatan Asli Daerah (Sidik, 2002). Hasil penelitian ini juga didukung oleh hasil penelitian terdahulu seperti Penelitian Pidelis, dkk (2016) menemukan bahwa Pendapatan perkapita berpengaruh positif terhadap PAD di kabupaten Nabire Papua tahun 2004-2013.

2. Pengaruh Jumlah Perusahaan Terhadap Pendapatan Asli Daerah Kabupaten Majene Tahun 2014-2018

Jumlah perusahaan merupakan sekumpulan perusahaan-perusahaan swasta yang berdiri di wilayah Kabupaten Majene dalam waktu tahun 2014-2018, dalam satuan perusahaan pertahun. Hasil penelitian ini membuktikan bahwa jumlah perusahaan berpengaruh positif dan signifikan terhadap pendapatan asli daerah Kabupaten Majene Tahun 2014-2018. Setiap terjadi kenaikan 1 skor jumlah perusahaan, maka akan diikuti oleh kenaikan pendapatan asli daerah sebesar 1,095 satuan. Semakin banyak jumlah perusahaan yang berdiri di Kabupaten Majene maka akan menambah kontribusi pajak ke Pemerintah Daerah Kabupaten Majene.

Kontribusi jumlah perusahaan terhadap pendapatan asli daerah dapat dilihat dari peningkatan pendapatan asli daerah secara 5 tahun terakhir, sektor perusahaan tentunya memberikan kontribusi terhadap penerimaan pajak daerah secara berkala, semakin banyak jumlah perusahaan maka akan menyerap lapangan kerja bagi masyarakat sebagai subyek pajak sehingga membangun rantai positif bagi pendapatan asli daerah berkelanjutan.

Perekonomian di Kabupaten Majene dikategorikan berkembang karena telah memproduksi barang dan jasa 
untuk mensuplai kebutuhan penduduk. Adanya perusahaan di suatu wilayah dapat membantu menaikan nilai barang dan jasa yang dihasilkan oleh daerah tersebut. Perusahaan yang berada di suatu daerah dapat menyediakan modal, teknologi serta tenaga kerja dimana perusahaan tersebut beroperasi. Operasinya membantu menambah barang dan jasa yang diproduksi didalam daerah, menambah penggunaan tenaga kerja dan pendapatan serta menambah ekspor. Operasi perusahaan multinasional merupakan bagian yang cukup penting kegiatan ekonomi suatu daerah dan nilai produksi yang disumbangkan dalam perhitungan pendapatan daerah.

Perusahaan di Kabupaten Majene dapat dikategorikan dalam 2 sektor yaitu Badan Usaha Milik Daerah dan Badan Usaha Milik Swasta. Pemerintah daerah juga mendapatkan pendapatan lain dari laba Badan Usaha Milik Daerah BUMD yang dimilki. Bagian laba Badan Usaha Milik Daerah adalah bagian keuntungan atau laba bersih dari perusahaan daerah atas badan lain yang merupakan badan usaha. Dari sector badan usaha milik swasta pemerintah daerah Kabupaten Majene mendapatkan pendapatan asli daerah dari pajak yang dibayarkan. Demikian juga perusahaan mendapatkan retribusi daerah dimana berdasarkan UU Nomor 28 Tahun 2009 Retribusi yang disebut adalah pungutan daerah sebagai pembayaran atas jasa atau pemberian izin tertentu yang khusus disediakan dan/atau diberikan oleh pemerintah daerah untuk kepentingan orang pribadi atau badan.

Hasil penelitian ini juga didukung oleh hasil penelitian terdahulu seperti Pidelis, dkk (2016) membuktikan Jumlah perusahaan berpengaruh positif terhadap PAD di kabupaten Nabire Papua tahun 20042013. Selain itu Nia Safitri (2018) menemukan ketika terjadi peningkatan pada jumlah Industri akan menaikkan Pendapatan Asli Daerah (PAD) pada Kabupaten/Kota yang ada di Provinsi Banten. Demikian juga penelitian Lokang (2016) Jumlah perusahaan (InJPR) signifikan (berpengaruh positif) terhadap pendapatan asli daerah (lnPAD) di Jawa Tengah.

3. Pengaruh Jumlah Penduduk Terhadap Pendapatan Asli Daerah Kabupaten Majene Tahun 2014-2018

Jumlah Penduduk adalah totalitas penduduk laki-laki dan perempuan dari segala umur yang menetap di wilayah kabupten Majene; dalam satuan jiwa pertahun. Hasil penelitian ini membuktikan bahwa jumlah penduduk berpengaruh secara positif dan signifikan terhadap pendapatan asli daerah Kabupaten Majene Tahun 20142018. Peningkatan jumlah penduduk akan meningkatkan pendapatan yang ditarik dari subyek pajak (penduduk) secara berkesinambungan. Hasil ini sesuai pernyataan Norfidwitya dalam Lokang (2016) menyampaikan besar maupun kecilnya pendapatan dapat di pengaruhi oleh jumlah penduduk. Jika jumlah penduduk meningkat maka pendapatan yang diterima akan meningkat.

Faktor-faktor Demografi (Kependudukan) Faktor kependudukan yang dapat mempengaruhi konsumsi rumah tangga adalah jumlah penduduk dan komposisi penduduk. Seiring dengan jumlah penduduk yang semakin banyak maka pengeluaran konsumsi rumah tangga juga semakin banyak meskipun pengeluaran ratarata orang atau perkeluarga lebih rendah. Pengeluaran konsumsi rumah tangga suatu negara akan sangat besar bila jumlah penduduk sangat banyak dan jumlah pengeluaran perkapita tinggi. Sebaliknya, pengeluaran komsumsi rumah tangga sedikit bila jumlah penduduk sedikit pula.

Semakin banyak penduduk yang berusia produktif (15-64 tahun) maka semakin besar tingkat konsumsi. Hal ini terjadi karena banyaknya jumlah penduduk yang bekerja maka pendapatanpun akan semakin besar. Apabila banyak penduduk yang tinggal diwilayah perkotaan, pengeluaran konsumsi juga makin tinggi. Sebab umumnya pola hidup masyarakat perkotaan lebih konsumtif dibanding masyarakat pedesaan.

Teori Peacok dan Wiserman yang merupakan salah satu Teori makro mengenai perkembangan pengeluaran pemerintah, dimana teori ini memandang bahwa pemerintah selalu berusaha untuk memperbesar pengeluaran sedangkan masyarakat tidak suka membayar pajak yang semakin besar untuk membiayai pengeluaran pemerintah yang semakin besar, sehingga teori Peacock dan Wiseman merupakan dasar dari pemungutan suara. Mereka percaya bahwa masyarakat mempunyai tingkat toleransi pajak, yaitu suatu tingkat dimana masyarakat dapat memahami besarnya pungutan pajak yang dibutuhkan pemerintah untuk membiayai pengeluaran pemerintah. Jadi masyarakat menyadari bahwa pemerintah membutuhkan dana untuk membiayai aktivitas pemerintah sehingga mereka memiliki kesediaan untuk membayar pajak, Sadono (2012).

Pertumbuhan penduduk secara tradisional dianggap sebagai salah satu faktor positif yang dapat memacu pertumbuhan ekonomi. Jumlah tenaga kerja yang lebih besar berarti akan meningkatkan tenaga kerja produktif, sedangkan pertumbuhan penduduk yang lebih besar berarti meningkatkan ukuran pasar domestiknya.

Hasil penelitian ini didukung oleh hasil penelitian terdahulu seperti penelitian Mayza, dkk. (2015) membuktikan bahwa jumlah penduduk mampu mempengaruhi PAD. Putu Adhi Guna Wijaya dan Ni Nyoman Yuliarmi (2019), juga dalam penelitiannya menemukan bahwa jumlah penduduk juga berpengaruh posiif dan signifikan terhadap PAD Kabupaten Badung. Demikian juga penelitian Nani Sari dkk (2013) menemukan bahwa jumlah penduduk yang produktif berpengaruh postif dan signifikan terhadap pendapatan asli daerah Kabupaten Morowali.

Hasil penelitian ini ternyata bertentangan dengan hasil Penelitian Demitianus (2018), ia justru menemukan bahwa jumlah penduduk memiliki pengaruh yang negatif terhadap PAD, jumlah penduduk meningkat maka PAD akan mengalami penurunan.

4. Pendapatan Perkapita merupakan faktor dominan terhadap PAD di Kabupaten Majene Tahun 20142018

Besarnya pendapatan per kapita merupakan salah satu indikator untuk mengukur tingkat kesejahteraan 
penduduk. Hasil analisis regresi menunjukkan diantara ketiga variabel faktor pendapatan asli daerah, variabel pendapatan perkapita memiliki unstandardized coefficients yang mencapai 3,530, sehingga diasumsikan memberikan pengaruh paling besar terhadap pendapatan asli daerah kabupaten majene tahun 2014-2018.

Besarnya pendapatan per kapita merupakan salah satu indikator untuk mengukur tingkat kesejahteraan penduduk. Selanjutnya kesejahteraan penduduk yang meningkat akan menumbuhkan pendapatan per kapita di Kabupaten Majene. Pendapatan perkapita Kabupaten Majene mengalami peningkatan dari tahun 2014 ke tahun 2016, pendapatan tertinggi pada tahun 2018 dan pendapatan terendah pada tahun 2014. Laju pertumbuhan pendapatan perkapita menunjukkan trend positif dalam 4 tahun terakhir, trend positif ini tentunya mendukung pertumbuhan pendapatan asli daerah Kabupaten Majene Tahun 2014-2018.

\section{KESIMPULAN DAN SARAN}

Hasil penelitian menyimpulkan bahwa pendapatan perkapita berpengaruh secara positif dan signifikan terhadap pendapatan asli daerah Kabupaten Majene Tahun 2014-2018. Pertumbuhan pendapatan perkapita dengan trend positif dapat meningkatkan jumlah pendapatan asli daerah Kabupaten Majene. Jumlah perusahaan berpengaruh positif dan signifikan terhadap pendapatan asli daerah Kabupaten Majene Tahun 20142018. Semakin banyak jumlah perusahaan yang berdiri di Kabupaten Majene maka akan menambah kontribusi pajak ke Pemerintah Daerah Kabupaten Majene. Jumlah penduduk berpengaruh secara positif dan signifikan terhadap pendapatan asli daerah Kabupaten Majene Tahun 2014-2018. Peningkatan jumlah penduduk akan meningkatkan pendapatan yang ditarik dari subyek pajak (penduduk) secara berkesinambungan. Pendapatan perkapita merupakan faktor yang paling dominan dalam berkontribusi meningkatkan pendapatan asli daerah Kabupaten Majene Tahun 2014-2018. Besarnya pendapatan per kapita merupakan salah satu indikator untuk mengukur tingkat kesejahteraan penduduk. Selanjutnya kesejahteraan penduduk yang meningkat akan menumbuhkan pendapatan per kapita di Kabupaten Majene

\section{DAFTAR PUSTAKA}

Asmurf, Makdalena F., Vikie A. Rumate, dan George M.V. Kawung. 2015. Pengaruh Pendapatan Dan Jumlah Penduduk Terhadap Pendapatan Asli Daerah (PAD) Di Kota Sorong. Jurnal Berkala Ilmiah Efesiensi. Vol.15 No. 05, Hal 727-737.

Badan Pusat Statistik, 2019. "Produk Domestik Regional Bruto Kabupaten Majene Menurut Lapangan Usaha pada Tahun 2014-2018. BPS Majene.

Demitianus Murib, Rosalina A.M. Koleangan, Krest D. Tolosang, 2018. Demitianus Murib Pengaruh
Jumlah Penduduk, Pendapatan Perkapita, Pdrb Terhadap PAD Di Kabupaten Mimika Provinsi Papua Jurusan Ekonomi Pembangunan, Fakultas Ekonomi Dan Bisnis, Universitas Sam Ratulangi Manado. Jurnal Berkala Ilmiah Efisiensi Volume 18 No. 01 Tahun 2018.

Ghozali, Imam (2016). Aplikasi Analisis Multivariate Dengan Program IBM SPSS 23.

Halim, Abdul. 2004. Akuntansi Sektor Publik Akuntansi Keuangan Daerah. Jakarta: Salemba Empat.

Hasanuddin, A., Said, M., \& Ruslan, M. (2020). Pengaruh Saluran Distribusi, Biaya Pemasaran Dan Volume Penjualan Terhadap Pendapatan Petani Kentang Di Kabupaten Gowa Sulawesi Selatan. Indonesian Journal of Business and Management, 3(1), 1-10.

Jaya, Wihana Kirana. 2002. Analisis Potensi Keuangan Daerah Pendekatan Makro. PPPEB UGM, Yogyakarta.

Josef Riwu, Kaho. 2007. Prospek Otonomi Daerah Negara Republik Indonesia. Jakarta: PT Grafindo Prasada.

Kusuma, Hendra. Desentralisasi Fisikal dan Pertumbuhan Ekonomi di Indonesia. Jurnal Ekonomi Kuantitatif Terapung, [S1], july 2016. ISSN 2303-0186. Available at: https://ojs.unud.ac.id/index.php/jek/article/view/227 35. Date accesed: 28 nov 2019. doi: hhtps/doi.org/10.24843/JEKT.2016.v09.i01.p01.

Lokang, Yustina Lastri (2016) Pengaruh Jumlah Perusahaan, Jumlah Penduduk Dan Pengeluaran Pemerintah Terhadap Pendapatan Asli Daerah Di Provinsi Jawa Tengah Tahun 1985-2014. S1 Thesis, Uajy.

Mardiasmo. Perpajakan Edisi Revisi 2011 .Yogyakarta: Penerbit Andi. 2011.

Murti, Bisma. 2003. Prinsip dan Metode Riset Epidemiologi. Gajah Mada Universty, Yogyakarta.

Nia Safitri. 2018. Peranan Sektor Industri Terhadap Pendapatan Asli Daerah (PAD) Di Provinsi Banten Tahun 2011-2015, Skripsi Universitas Islam Indonesia Fakultas Ekonomi Yogyakarta.

Nugraha, Yoga Nurdiana. 2019. Pelaksanaan Disentralisasi Fisikal Di Indonesia. www.kemenku.go.id Diakses pada 29 September 2019.

Nyoman, Suartha; Murjana Yasa, I Gst Wayana. Pengaruh Pertumbuhan Ekonomi, Migrasi Masuk Terhadap Pertumbuhan Penduduk dan Alih Fungsi Bangunan Penduduk Asli Kota. Jurnal Ekonomi Kuantitatif Terapung, [S1], may 2017. ISSN 23030186. Available at: https://ojs.unud.ac.id/index.php/jek/article/view/227 35. Date accesed : 28 nov 2019. doi: hhtps/doi.org/10.24843/JEKT.2016.v09.i01.p01.

Peraturan Pemerintah Nomor 106 Tahun 2000 tentang Pengelolaan Dan Pertanggungjawaban Keuangan 
Dalam Pelaksanaan Dekonsentrasi Dan Tugas Pembantuan.

Peraturan Pemerintah Nomor 58 Tahun 2005 tentang Pengelolaan Keuangan Daerah.

Peraturan Pemerintah Nomor 65 Tahun 2001 tentang Pajak Daerah.

Peraturan Pemerintah Nomor 66 Tahun 2001 tentang Retribusi Daerah.

Pidelis Murib, Debby C. Rotinsulu, Dan Krest D. Tolosang. 2016. Pengaruh Pendapatan Perkapita, Jumlah Perusahaan Dan Jumlah Penduduk Terhadap Pendapatan Asli Daerah Di Kabupaten Nabire Papua Tahun 2004-2013. Jurnal Berkala Ilmiah Efisiensi Volume 16 No. 01 Tahun 2016, Jurusan Ekonomi Pembangunan, Fakultas Ekonomi dan Bisnis, Universitas Sam Ratulangi, Manado, Indonesia.

Prana, Rindani Rezki. Analisis Faktor-Faktor yan Mempengaruhi Pendapatan Asli Daerah (PAD) Kota Tebing Tinggi. Jurnal Ilman, Vol. 4, No. 1, Pebruari 2016. ISSN 2355-1488. Available at: https://ojs.unud.ac.id/index.php/jek/article/view/227 35 Date accesed : 28 nov 2019. doi: hhtps/doi.org/10.24843/JEKT.2016.v09.110.p10.

Sidik, Machfud. 2002. "Optimalisasi Pajak daerah dan Retribusi Daerah dalam Rangka Meningkatkan Kemempuan Keuangan Daerah.”. Makalah dalam acara orasi ilmiah dengan tema "Strategi Meningkatkan Kemampuan Keuangan Daerah Melalui Penggalian Potensi Daerah dalam Rangka Otonomi Daerah" yang diselenggarakan oleh STIA LAN Bandung

Soeharno. 2006. Teori Ekonomi Mikro. Yogyakarta: Andi.

Sugiyono. 2014. Metode Penelitian Pendekatan Kuantitaif Kualitatif Dan R\&B. Bandung: Alfabeta.

Sukirno, Sadono. 1999. Pengantar Teori Makroekonomi. Jakarta: RajaGrafindo Persada.

Undang-Undang Nomor 1 Tahun 2004 tentang Perbendaharaan Negara.

Undang-Undang Nomor 12 Tahun 2008 tentang perubahan kedua atas Undang-Undang Nomor 22 Tahun 1999 tentang Pemerintah Daerah.

Undang-Undang Nomor 15 Tahun 2004 tentang Pemeriksaan Pengelolaan dan Tanggung Jawab Keuangan Negara.

Undang-Undang Nomor 17 Tahun 2003 tentang Keuangan Negara.

Undang-Undang Nomor 25 Tahun 2004 tentang Sistem Perencanaan Pembangunan Nasional.

Undang-Undang Nomor 28 Tahun 2009 tentang Pajak dan Retribusi Daerah.

Undang-Undang Nomor 32 Tahun 2004 tentang perubahan atas Undang-Undang Nomor 25 Tahun 1999 tentang Perimbangan Keuangan antara Pemerintah Pusat dan Daerah. 